\title{
O turismo étnico como ferramenta para o etnodesenvolvi- mento da aldeia Tabaçu Reko Ypy, Itanhaém-Peruíbe (SP)
}

\section{Ethnic tourism as a tool for ethnodevelopment of the village Tabaçu Reko Ypy, Itanhaém-Peruíbe (SP, Brazil)}

\section{Cássia Aparecida Praeiro Mateus, Andrea Rabinovici}

\section{RESUMO}

A presente pesquisa acompanhou as vivências turísticas ocorridas entre indígenas da etnia Ñandeva ao longo dos anos de 2013 a 2015 na aldeia Tabaçu Reko Ypy. Analisou as possíveis consequências e os impactos ao etnodesenvolvimento exercido pelo turismo étnico. Esta comunidade desenvolve e pratica esta atividade como uma ferramenta de apoio à geração de renda alternativa na busca de melhores condições de vida em prol da recuperação do seu território gravemente degradado pela atividade de mineração. Afora isso visa obter um auto sustento que colabore com o resgate das suas tradições. Por se tratar de uma aldeia recentemente formada, nenhuma literatura específica sobre este povo foi encontrada. Basicamente todos os registros e informações sobre a sua política, comportamento social e cultural foram obtidas através de entrevistas semiestruturadas, participação em vivências e doação de registros realizada pelos próprios indígenas. Através deste estudo pôde-se notar consequências diversas advindas do turismo étnico e refletir sobre possíveis futuros impactos. Conclui-se que, através das ações exercidas pelo povo Ñandeva, a possibilidade em se fazer uso de novas ferramentas e diretrizes servirão de apoio para o alcance de um etnodesenvolvimento autônomo sob o olhar de um modelo de turismo inclusivo capaz de gerar renda, que respeite a cultura local e que também busque promover o equilíbrio ambiental.

PALAVRAS-CHAVE: Etnodesenvolvimento; Turismo Étnico; Etnia Ñandeva. 


\section{ABSTRACT}

This research has followed the tourist experiences that occurred among indigenous ethnic Nandeva over the period from 2013 to 2015 as well as analyzing the possible consequences and impacts on the ethnodevelopment carried out by the ethnic tourism. The village develops and performs this activity as a supporting tool for generating alternative income with the purpose of improving their living conditions and recovering their territory, which was seriously degraded by mining activities. Furthermore, the community aims to reach self-sufficiency so that they will be able to recover their traditions. I should make it clear that, due to the fact that I have dealt with a recently formed village, no specific literature about its people has been found. Basically, all the documents and information about their politics, social behavior and culture have been obtained through semi-structured interviews, participation in field experiences and documents provided by the indigenous people themselves. This study noted several consequences arising from ethnic tourism and reflect on possible future impacts. It is concluded that, through the actions carried out by the people, Nandeva make use of new tools and guidelines will serve as a support to the achievement of an ethnodevelopment as under the gaze of a inclusive tourism model capable of generating income, that respects local culture and which also seek to promote the environmental balance.

KEYWORDS: Ethnodevelopment; Ethnic tourism; Ethnicity Ñandeva.

\section{O Etnodesenvolvimento entre o Tradicional e o Contemporâneo}

Os índios do Brasil não se resumem a apenas um povo, mas sim em muitos povos diferentes entre si. Cada qual tem seus próprios idiomas, costumes, habilidades tecnológicas, atitudes estéticas, crenças religiosas, organização social e filosofia peculiares, resultados estes, de experiências de vida acumuladas e desenvolvidas por milhares de anos (RODRIGUES, 2002).

Além da luta pela demarcação de suas terras, os povos indígenas enfrentam também desafios de como sobreviver na terra já demarcada e proteger os seus conhecimentos e patrimônios materiais e imateriais (FARIA, 2007).

Esta população, em sua grande maioria, vem enfrentando uma acelerada e complexa transformação social, necessitando buscar novas respostas para a sua sobrevivência física e cultural, para assim, poderem obter e garantir melhorias na qualidade de vida (FUNAI, 2015).

Para tanto, se faz necessária a compreensão e a prática de um sistema de etnodesenvolvimento. Conforme exposto por Azevedo (2014), o etnodesenvolvimento tem como principal característica desenvolver um grupo tradicional ${ }^{1}$ específico com base em seus conhecimentos e na sua cultura, que seja capaz de evoluir e produzir de maneira autônoma, disseminando sua cultura por meio da autogestão, a fim de promover um desenvolvimento local para a sustentabilidade. 
O etnodesenvolvimento pressupõe e exercita a capacidade social dos atores tradicionais, por meio de projetos definidos de acordo com seus valores e anseios, alicerçados os recursos reais e potenciais disponíveis no seu território, na utilização de seus significados e experiências históricas e coletivas, [para] guiar de forma autônoma seu desenvolvimento (SILVA; CARVALHO, 2008, p.5)

Batalla (1982) se refere ao etnodesenvolvimento como uma ferramenta na qual as comunidades possam ser efetivamente autogeridas para 0 seu auto sustento. Stavenhagen (1997, p.57), define etnodesenvolvimento como o desenvolvimento que mantém o diferencial sociocultural de uma sociedade, ou seja, sua etnicidade. Neste contexto, o desenvolvimento tem pouco ou nada a ver com indicadores de "progresso" no que se refere ao produto interno bruto, renda per capita, mortalidade infantil, nível de escolaridade, entre outros. O autor conceitua o termo como a capacidade de os povos tradicionais possuírem real poder e direito por suas terras, por seus recursos, organização social e cultural, sendo livres para negociar com o Estado sobre o estabelecimento de relações segundo o seu interesse.

Azanha (2002; p.32), envolve em seus estudos referentes as sociedades indígenas brasileiras, pontos que podem ser tomados como metas ideais de um projeto de etnodesenvolvimento sustentado: a) segurança territorial, satisfazendo plenamente as necessidades de expansão da sociedade indígena; b) usufruto exclusivo dos recursos naturais; c) demanda por produtos manufaturados e meios para consegui-los; d) tempo empregado na geração de recursos financeiros internos para a aquisição de produtos manufaturados; e) escala ou nível das necessidades impostas pelo contato e identificação de como cada sociedade indígena específica fixa ou fixou esse nível; f) internalização dos recursos financeiros gerados pelos canais tradicionais de distribuição e circulação. Essas questões, portanto, são os pressupostos para a execução de qualquer projeto na direção do etnodesenvolvimento.

Segundo Faria (2007), o artigo 231 da Constituição Federal Brasileira de 1988 confere a posse e o usufruto exclusivo das Terras Indígenas (Tl's) com atividades para garantir sua sobrevivência física e cultural. Assim, de certa maneira, o turismo e/ou o ecoturismo podem ser considerados como uma destas atividades, desde que sejam planejados e gerenciados por estes povos. Para que isso se torne possível, é fundamental haver capacitação técnica e parcerias cujas propostas e os objetivos se mantenham em missões honestas e de mesma afinidade com os indígenas de cada comunidade e região. Para Grünewald (2003, p.52), o etnodesenvolvimento não é a única saída para casos como este, mas é um pressuposto positivo que vale ser testado. 


\title{
O Turismo e a sustentabilidade nas comunidades indígenas
}

Segundo Banducci Jr. e Barretto (2001), o turismo é um fenômeno extremamente complexo, mutável, capaz de se operar de múltiplas maneiras e sob diversas circunstâncias.

Os povos indígenas têm pensado na atividade turística como uma alternativa sustentável de desenvolvimento local, empreendida a partir de critérios estabelecidos pelos próprios grupos étnicos (BARTHOLO et al., 2009).

Para tanto, em sua diversidade, se faz necessário estudar o fenômeno e saber diferenciar as suas distintas modalidades e segmentos, desdobrados a partir do turismo de massa e do alternativo. Dentro do turismo alternativo, podem ser incluídos o ecoturismo, o turismo chamado de ecológico, o rural, o sustentável, 0 de base local/base comunitária, 0 de aventura, o cultural, de pesca, o étnico, o pedagógico, entre outros (SNPT, 2005).

O turismo de massa se refere ao deslocamento de um grande contingente de pessoas a um determinado local de visitação (BARRETO, 1995, p.48). Um dos segmentos desta modalidade é o turismo de sol e praia. Segundo a Organização Mundial do Turismo (2010, p.14), "o turismo de sol e praia constitui-se das atividades turísticas relacionadas à recreação, entretenimento ou descanso em praias, em função da presença conjunta de água, sol e calor".

Castro (2009), argumenta que, embora o turismo de massa possa gerar consideráveis lucros e empregos, gera também a transformação e a degradação do ambiente

\begin{abstract}
A chamada indústria do turismo, caracterizada por vincular um modelo estruturante, impactante de transformação do local, para receber os turistas, além de ter uma visão essencialmente mercadológica, vem agindo de forma a não considerar e respeitar a população local e o meio ambiente, quanto da implantação de estruturas turísticas para o desenvolvimento da atividade. Busca-se atrair o maior número possível de turistas, em um planejamento em curto prazo, que possa devolver o investimento e promover o lucro rapidamente. Este modelo impulsiona ainda mais o consumo de massa, além de provocar o esgotamento do local, em poucos anos (CASTRO, 2009, p.2).
\end{abstract}

Como alternativa sobre um pensar sustentável na conservação do meio ambiente e da cultura local surge o ecoturismo visando a conservação de ecossistemas de modo a promover o bem-estar da comunidade local. É importante ressaltar que sob a égide do ecoturismo vem se praticando uma má interpretação deste conceito. Muitas localidades são divulgadas devido ao potencial ecoturístico, embora a atividade praticada não seja caracterizada como tal (LINDIBERG; HAWKINS, 1999). 
Dentro da sua essência, a atividade ecoturística deve se desenvolver respeitando critérios socioambientais que irão dar sustentabilidade a atividade, porém o que se observa na prática, em algumas localidades de potencial ecoturístico é uma distorção deste conceito ou a apropriação de roteiros ecoturísticos por outras modalidades de turismo, ou seja, a exploração dos ambientes naturais pelo turismo sem nenhum respeito a estes critérios. Assim, há uma distorção da realidade local, que nem sempre usufrui os benefícios do turismo e ainda arca com uma série de impactos por ele ocasionado (OLIVEIRA, 2007, p.195).

Segundo a Secretaria Nacional de Políticas de Turismo (SNPT, 1997), a sustentabilidade deve ser entendida como o princípio estruturador de um processo de desenvolvimento centrado na eficiência econômica, na diversidade cultural, na proteção, conservação do meio ambiente e na equidade social.

O desenvolvimento local, também conceituado como um processo endógeno é um processo de crescimento econômico e de mudança estrutural, liderado pela comunidade local, que busca satisfazer as suas necessidades e demandas por meio de sua participação ativa nos processos de desenvolvimento. A perspectiva do desenvolvimento local acontece quando as pessoas que estão envolvidas são beneficiadas em seus territórios (FABEIRO, 2004).

De acordo com Hanai (2012), este perfil de desenvolvimento para ser consistente e sustentável deve levar ao dinamismo e à viabilidade econômica, mobilizando e explorando as potencialidades locais e contribuindo para elevar as oportunidades sociais e, ao mesmo tempo, deve assegurar a conservação dos recursos naturais locais, que são as bases de suas potencialidades.

Sobre tais questões, a SNPT (1997), afirma que, o desenvolvimento sustentável deve ser aplicado a qualquer segmento do turismo e em qualquer escala, desde o turismo de massa e seus grandes resorts até aquele desenvolvido em pequena escala e em lugares ambientalmente frágeis, de ecossistemas únicos e natureza preservada.

O desenvolvimento do turismo sustentável vai ao encontro das necessidades atuais dos turistas e das regiões anfitriãs e, ao mesmo tempo, garante oportunidades para o futuro. É a gestão de todos os recursos de tal forma que as necessidades econômicas, sociais e estéticas possam ser satisfeitas mantendo-se, ao mesmo tempo, a integridade cultural, os processos ecológicos essenciais, a diversidade biológica e os sistemas de apoio à vida (ORGANIZAÇÃO MUNDIAL DO TURISMO, 2003).

$\mathrm{Na}$ aldeia Tabaçú Reko Ypy, a líder Itá Mirim², classifica tais atividades desenvolvidas em suas terras como turismo pedagógico. 
O turismo educacional, ou pedagógico, tem por objetivo executar viagens que promovam estudos do meio, ou seja, traçar uma ponte entre o conhecimento teórico discutido em sala de aula e uma experiência prática mais próxima da realidade. Parte do pressuposto de que os estudantes, quando colocados em contato com ambientes naturais, culturais ou sociais, reconhecem e assimilam novos conceitos, valores e modos de vida.

Este tipo de prática visa relacionar lazer com conhecimento para que a diversidade seja reconhecida, justificando a relação desse segmento com o turismo sustentável e a proximidade com o ecoturismo, já que este também tem como um dos seus objetivos promover a educação ambiental e o reconhecimento de culturas diferentes (FACO; NEIMAN, 2010, p. 53).

Esta classificação se encaixa neste contexto quando 0 povo Nandeva ${ }^{3}$ recebe visitas de estudantes de escolas, cursos técnicos ou superior. Porém, as vivências ocorridas na aldeia Tabaçú Reko Ypy 4 apresentam características que vão além do turismo pedagógico.

Sob a ótica do turismo cultural, este segmento se relaciona à vivência do conjunto de elementos significativos do patrimônio histórico e cultural e dos eventos culturais, valorizando e promovendo os bens materiais e imateriais (SNPT,1998).

Com relação ao ecoturismo, este segmento possui estreita relação com o turismo desenvolvido próximo a reservas indígenas, pois suas atividades são realizadas em áreas naturais, utilizando-se de atrativos culturais visando à sustentabilidade como objetivo primordial. Existem diversas outras denominações que se relacionam e se encaixam dentro deste contexto, como o etnoturismo, o turismo indígena, o sustentável, o cultural, o de base comunitária/de base local entre outros, relacionados ao turismo alternativo. Todas estas denominações ou classificações se aproximam da ideia do turismo realizado em áreas indígenas, acompanhadas de ideologias relacionadas a conservação ambiental, cultural e a sustentabilidade (OMT, 2010).

Faco e Neiman (2010), apresentam três características fundamentais no ecoturismo que se mantém presentes no que constitui o chamado tripé da sustentabilidade dessa atividade: a) Garantia de conservação ambiental; b) Educação Ambiental e c) Benefícios às comunidades receptoras.

Dentro das diversas modalidades abrangidas pelo turismo e, de acordo com o cenário desta pesquisa, o turismo praticado na aldeia Tabaçú Reko Ypy consiste na segmentação turismo alternativo e, com possibilidades de se constituir enquanto experiência de turismo étnico, o qual "relaciona as tradições e o estilo de vida de um determinado grupo" (OMT, 2003); como também o turismo de base comunitária, o qual expressa valores de cunho social, natural e cultural por meio de uma interação positiva e do compartilhamento de experiências, capaz de promover a conservação e seguir de maneira pertinente os critérios de desenvolvimento sustentável 
(FACO; NEIMAN, 2010). Desde 2008 o Ministério do Turismo (MTur), passou a reconhecer institucionalmente a existência do turismo de base comunitária ao publicar o edital MTur no 001/2008, definindo-o da seguinte maneira:

O turismo de base comunitária é compreendido como um modelo de desenvolvimento turístico, orientado pelos princípios da economia solidária, associativismo, valorização da cultura local, e, principalmente, protagonizado pelas comunidades locais, visando à apropriação por parte dos benefícios advindos da atividade turística (MTUR, 2008).

Von Held (2013), afirma que existe um crescente interesse pelo turismo em comunidades indígenas, de maneira bilateral, ou seja, além da sociedade em geral, algumas comunidades manifestam interesse sobre tal ação. Mas, para tanto, adverte sobre o quão é necessário um aprofundamento nos estudos desta temática para que tal atividade não se torne danosa aos protagonistas deste roteiro.

Segundo Juliano e Rabinovici (2010), pensar o turismo em território indígena preconiza e exige uma avaliação detalhada sobre as especificidades culturais de cada comunidade, a fim de não ocorrerem riscos relacionados à estereotipação do atrativo.

De imediato, é preciso assinalar que os impactos do turismo não são iguais em todos os lugares, pois diversos fatores determinam a expansão desta atividade em um dado momento e espaço, tais como: volume e perfil da demanda turística; características de oferta; acessibilidade; infraestrutura utilizada como: tipos de transporte e meios de hospedagem; localização e distribuição espacial dos equipamentos turísticos - hotéis, marinas, parques temáticos, etc. E também a própria organização do território em si, como: recursos naturais e culturais disponíveis, nível de desenvolvimento econômico, estrutura social e política, entre outros fatores (TARLOMBANI, 2002).

As atividades exercidas na aldeia Tabaçú Reko Ypy são nomeadas pelo povo Ñandeva de vivência, ou seja, visam oferecer ao turista uma experiência de lazer e conhecimento sobre a sua história, cultura e conservação. Eles deixam claro para o visitante sobre a importância e o desafio de resgate e fortificação de suas tradições, bem como combater o preconceito e o descaso que enfrentam diariamente. Segundo a SNPT (1998), vivenciar implica, essencialmente em duas formas de relação do turista com a cultura ou algum aspecto cultural: a primeira refere-se ao conhecimento, entendido como a busca em aprender e entender os anfitriões; a segunda corresponde a experiências participativas, contemplativas e de entretenimento, que ocorrem em função da experiência de visitação.

As vivências realizadas na aldeia são praticadas esporadicamente. Esta atividade serve como uma ferramenta de apoio à geração de renda alternativa na busca de melhores condições de vida em prol da recuperação do seu território que foi gravemente degradado pela atividade de mineração durante cinquenta anos e também visa obter um auto sustento que colabore 
com o resgate das suas tradições. De acordo com Meneses (1996), o tipo de turismo que se almeja dependerá do tipo de relações que são julgadas aceitáveis e desejáveis entre os seres humanos, ou seja, do tipo de sociedade pelo qual optamos.

\section{Metodologia}

A linha metodológica deste estudo seguiu os preceitos da pesquisa descritiva, de abordagem qualitativa, com o estudo de caso etnográfico. Para a investigação do objeto de pesquisa, entre os anos de 2013 a 2016 foram realizados dez encontros, nos quais ocorreram uma entrevista específica em 2013, sete entrevistas abertas no período entre 2013 a 2016 e duas participações em eventos: o Vivência na Aldeia II, em 2013 e o I Viva Okatur - Nhanderekó ${ }^{5}$, em 2015. Todas as entrevistas foram autorizadas e registradas por meio de gravação em áudio e vídeo. Foi possível dialogar e interagir com todos os membros da aldeia, porém, as informações foram cedidas pelas autoridades indígenas, o Morubixaba ${ }^{6}$, Nhantze ${ }^{7}$ e a líder e professora, Itá Mirim, por serem os responsáveis e porta-vozes da comunidade. Também, para complemento das informações ocorreu a análise de documentos doados pelo povo Ñandeva, documentários contendo depoimentos pessoais sob diversos assuntos em questão, observação participante de maneira ocasional e, além disso, a participação nas vivências e atividades de turismo étnico aplicados na aldeia Tabaçú Reko Ypy.

Ao se estudar a temática indígena se faz necessário conhecer as especificidades de suas dinâmicas sociais, culturais e cosmológicas. É fundamental saber que cada etnia tem um enfoque e uma experiência diferenciada no significado de sua existência, não havendo uma lógica cultural que englobe todas as comunidades indígenas (VON HELD, 2013).

Segundo Godoy (1995), a pesquisa qualitativa não busca enumerar e/ou medir os eventos estudados, nem emprega modelos instrumentais estatísticos na análise dos dados, mas assume envolver a obtenção de informações descritivas sobre pessoas, lugares e processos interativos pelo contato direto do pesquisador com a situação estudada, procurando compreender os fenômenos segundo a perspectiva dos sujeitos, ou seja, dos participantes da situação em estudo.

O estudo de caso é um método que consiste em uma investigação empírica, sendo um método que abrange diferentes fontes de evidência planejamento, técnicas de coleta de dados e análise dos mesmos (YIN, 2005). Sua definição é tida também como uma metodologia que analisa propriedade de um caso ou de um fenômeno (CAMPBELL; STANLEY, 1963).

A interpretação e a análise de dados deste trabalho utilizam-se das descrições e narrativas etnográficas, conduzidas através da observação participativa e espontânea. Segundo Silva e colaboradores (2011), o termo etnografia tem sido usado para designar o estudo dos fenômenos sociais a partir de uma investigação em que o pesquisador participa ativamente no contexto pesquisado com o intuito de entender os significados das ações e dos comportamentos dos sujeitos que vivem e se relacionam neste 
ambiente. Para Moreira (2009), a etnografia é um método e um ponto de partida, é a interação entre o pesquisador e os seus objetos de estudos. É uma ferramenta de grande utilidade para se estudar e compreender uma cultura, a maneira de vida de um grupo de pessoas sob o contexto de suas ideias.

Para Jones (1985), a entrevista em profundidade deve ser absolutamente aberta, no máximo com alguns tópicos a serem discutidos, mas sem nenhuma pergunta preconcebida, porém, tal fato pode ser uma aproximação válida para a etnografia tradicional, ou quando a entrevista é o primeiro contato do entrevistador com o entrevistado. Segundo a autora, neste caso, a etnografia crítica pode incluir uma entrevista mais dirigida, com perguntas específicas derivadas de uma crítica social mais abrangente. Particularmente, isso pode acontecer quando uma observação participante detalhada tem revelado aspectos importantes que merecem ser examinados com maior profundidade. Para melhor obtenção dos dados e interpretação, foi permitida a filmagem em todos os encontros.

\section{A T.I Piaçaguera: histórico, conflitos e turismo}

A Terra Indígena (TI) Piaçaguera está situada na divisa dos municípios de Itanhaém e Peruíbe, litoral sul de São Paulo. Piaçaguera significa 'terra de passagem', local este que sempre foi utilizado como via de passagem aos indígenas de costume nômade, justamente por apresentar características desfavoráveis a moradia, mesmo que momentânea.

Esta TI é cortada pela rodovia SP 55 Padre Manoel da Nóbrega. Segundo, a Comissão Pró-Indio de São Paulo (2013), não foram localizados estudos que analisem os impactos da estrada para os índios. A região é considerada a última remanescente à beira mar, onde ainda permanece a vegetação de restinga nativa estendida até a areia da praia do litoral sul do Brasil. A área de restinga é um ecossistema delicado, composto por solo sedimentar arenoso e considerável teor de salinidade. A TI Piaçaguera é um território extremamente vulnerável pela proximidade da área urbana, pela existência de uma estrada de uso intenso, pelo fluxo de turistas e pelos impactos causados por mais de cinquenta anos de atividade minerária no interior de suas terras (CPISP, 2010). A atividade minerária extraía areia quartzosa e areia de fundição da área, material este, em sua maioria, destinado à construção civil (CPISP, 2013).

Essa área abriga 55 famílias com aproximadamente 200 indígenas da etnia Tupi-Guarani - mistura da etnia tupinambá com a etnia guarani entre crianças, jovens e adultos, distribuídas em cinco aldeias: Piaçaguera, Nhamamndú Mirim, Taniguá, Pekoá Kwaray e Tabaçú Reko Ypy. A criação de novos aldeamentos se deu pelo fato da ocupação territorial ou por conflitos em sua organização política interna tradicional.

Para Baines (2014, s/p.), as Tl's são fundamentais por dois motivos: elas garantem a sobrevivência dos povos indígenas e compõem os espaços que ainda possuem cobertura vegetal. "Ao sobrevoar o Parque Indígena do Xingu e o Estado de Rondônia, por exemplo, se vê claramente que as áreas de floresta que sobram coincidem com as terras indígenas", argumenta. 
Embora estes conflitos os privam de praticar os seus costumes de maneira plena, os indígenas dentro do contexto capitalista criam as suas estratégias de sobrevivência e fortalecimento. Através de suas ações e discursos, é possível notar que possuem consciência sobre o processo histórico que atravessam. Eles sabem, que este é um momento de agir com determinação pelo fortalecimento de suas bases étnicas e pela busca de uma nova posição no panorama nacional. Eles sabem também, por meio da tradição e de sua história oral, que a história que se lhes impôs os reduziu a uma posição de marginalidade demográfica e social no contexto político em que vivem (GOMES, 2012).

\section{A aldeia Tabaçú Reko Ypy}

A aldeia Tabaçú Reko Ypy foi criada em 26 de maio de 2012 e está situada no km 339 da Rodovia Padre Manoel da Nóbrega - BR 101, dentro da TI Piaçaguera. A área de restinga, ou Jundú ${ }^{8}$, abriga uma vegetação densa com arbustos e árvores em solo arenoso revestindo desde as dunas das praias até o sopé da Serra do Mar.

Este povo pertence a etnia Guarani Ñandeva, classificação esta delineada desde a demarcação da TI Piaçaguera, fato recente, ocorrido em meados de 2012, aproximadamente, segundo as informações obtidas com a líder Itá Mirim?.

A necessidade de se fundar uma nova aldeia se baseia em diversos conflitos enfrentados ao longo de anos. Itá Mirim ${ }^{10}$ nos conta um pouco sobre este fato:

\begin{abstract}
Assim como existem líderes na sociedade que desenvolvem trabalhos bons e ruins para suas cidades, estados e país, enfim, nós, temos nossa organização política interna e como tal, estávamos em uma aldeia em que a liderança não focava o nosso propósito tradicional de fortalecimento. Esse propósito foi dilacerado pelo líder nos proibindo até de praticar a nossa tradição, isso enfraqueceu nosso espírito e por mais que lutássemos para continuar nossos objetivos, não conseguíamos apoio da maioria da comunidade, que também foram contaminados com a sombra do esquecimento da nossa tradição, focando em individualismo e viver por viver.

Eu, como líder, não consegui ver a divisão das doações que chegavam e não beneficiavam as famílias que mais necessitavam, não consegui assistir as necessidades básicas da aldeia, nossos rituais e festas tradicionais sendo substituídas por interesses esportivos, serem sufocados por futebol, chegando somente doações como jogo de camisa, bola e outros, e isso realmente nos deixou muito tristes.

Entre essas e outras coisas ruins, veio uma coisa boa, a demarcação de nossa terra possibilitando a ocupação territorial em definitivo. E assim, poderemos seguir em busca de nossos objetivos" (ITÁ MIRIM, 2015).
\end{abstract}


Até o ano de 2013 a aldeia Tabaçú Reko Ypy era composta por sete famílias, totalizando em treze indivíduos, destes, cinco são crianças. Até este período havia oito famílias, porém, estes ainda se mantêm nômades e permanecem migrando por outros territórios. Em 2015, o número de indivíduos aumentou para quatorze adultos e dez crianças.

A aldeia é dividida em dois espaços: o espaço tradicional chamado de Nhanderekoa Ymã (figura 1) e o espaço contemporâneo conhecido como Nhanderekoa Koay (figura 2). O espaço tradicional é a reprodução de uma aldeia tupinambá do século XVI conforme é conhecido e transferido por meio da oralidade de seus ancestrais. Neste local, se pratica e se ensina diariamente os mais jovens sobre toda a sua tradição cultural e conhecimentos da natureza. É neste ambiente que os indígenas produzem suas esteiras e redes de cipó, fazem fogo, praticam a oralidade, entre outras atividades tradicionais que são revividas. O espaço contemporâneo é o local onde há a escola, algumas casas de barro - pau-a-pique e superadobe ${ }^{11}$, a cozinha comunitária, o banheiro seco ${ }^{12}$ e demais ferramentas tecnológicas que auxiliam em seus trabalhos de acordo com as suas necessidades atuais: fazem uso basicamente de um antigo computador, livros, canetas, quadro de anotações, lousa, giz e um simples automóvel para colaborar nos deslocamentos até a cidade, quando preciso.

Para obtenção de renda, vez ou outra, vão para a feira da cidade vender seus artesanatos, orquídeas e demais plantas ornamentais. Itá Mirim leciona em escolas indígenas da região, Tabaçú Reko Ypy e Nhamandú Mirim. Algumas famílias recebem o benefício social da bolsa-família. Como colaboração à renda, esporadicamente dão espaço as atividades que envolvem o turismo étnico na aldeia.

A sabedoria dos artesanatos se faz presente não somente para 0 comércio, Nhantze conta que, tradicionalmente, quando nasce uma nova criança na aldeia, os avós tecem um colar de proteção para abençoá-la. Segundo a tradição, o colar deve ser feito de capiá $^{33}$ e são diferentes de acordo com o gênero.

A fogueira Tataruçú ${ }^{14}$ é um símbolo sagrado para o povo Ñandeva. Segundo Itá Mirim ${ }^{15}$, todas as manhãs e tardes se pratica o Nhanderekó ${ }^{16}$. Os indígenas cantam ao redor da fogueira em agradecimento a Nhanderú17 e, gostam de se reunir a noite para contar histórias sobre seus antepassados, falar sobre as suas crenças e lendas místicas. Assam batatadoce, palmito e banana verde no pé da fogueira, fumam cachimbo, cantam e dançam durante quase toda a noite. Neste momento, partilham conhecimentos, revivem histórias, praticam o seu idioma nativo, o tupi e discutem sobre ideias de trabalho e melhorias para a aldeia.

Como o principal objetivo se refere ao resgate cultural, fortalecer o idioma é uma das metas da comunidade. Os mais velhos estão tentando tornar fluente a linguagem tradicional falando e ensinando diariamente os jovens e as crianças. As crianças, por sua vez, estudam na escola indígena e também em escolas da cidade (VIVAOKATUR, 2015). 
Segundo Oliveira (2006), os grupos indígenas brasileiros podem ser compreendidos como comunidades tradicionais, cuja transferência da cultura ocorre por meio da oralidade, uma vez que tais povos têm pouco domínio da escrita, não existindo literatura extensa no próprio idioma. Por esta razão, o povo Ñandeva está dando início a projetos linguísticos, resgatando o seu idioma e praticando-o também em escritas, para que futuramente possam montar materiais de apoio ao ensino-aprendizagem a todos da aldeia. De acordo com Hobsbawm (1984, p.10), "o 'costume', nas sociedades tradicionais, tem a dupla função de motor e volante. Não impede as inovações e pode mudar até certo ponto, embora evidentemente seja tolhido pela exigência de que deve parecer compatível ou idêntico ao precedente".

Outro grande problema que a comunidade enfrenta é com relação à assistência municipal e federal, pois como a TI está localizada na divisa dos municípios de Itanhaém e Peruíbe nenhum órgão os assume, um passa a responsabilidade para o outro, o que acarreta na falta de socorro médico emergencial SAMU, no acesso aos postos de saúde, no descaso as escolas indígenas, a falta de recursos e merenda, não recebem cesta básica, a estrada de acesso a aldeia se encontra em péssimas condições, dificultando assim o seu acesso, falta de fiscalização territorial, precariedade com relação a energia elétrica e água potável (VIVAOKATUR, 2015).

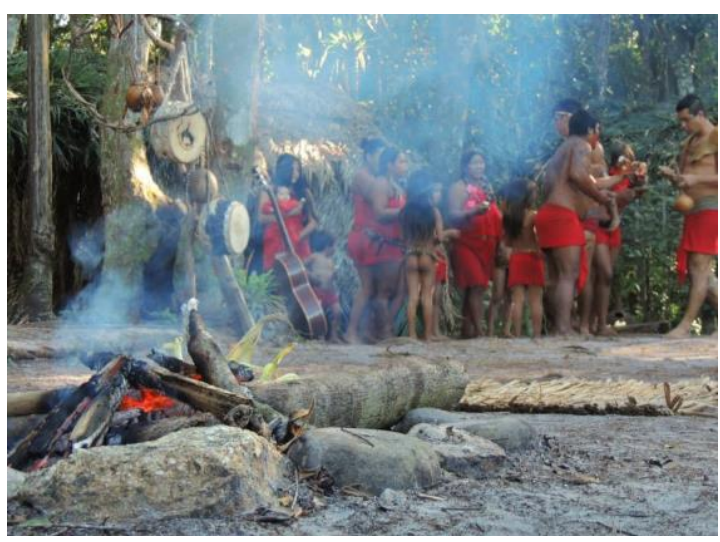

Figura 1: Espaço Tradicional da aldeia Tabaçú Reko Ypy. Itanhaém-Peruíbe/SP

Figure 1: Traditional space of village Tabaçú Reko Ypy. Itanhaém-Peruíbe/SP

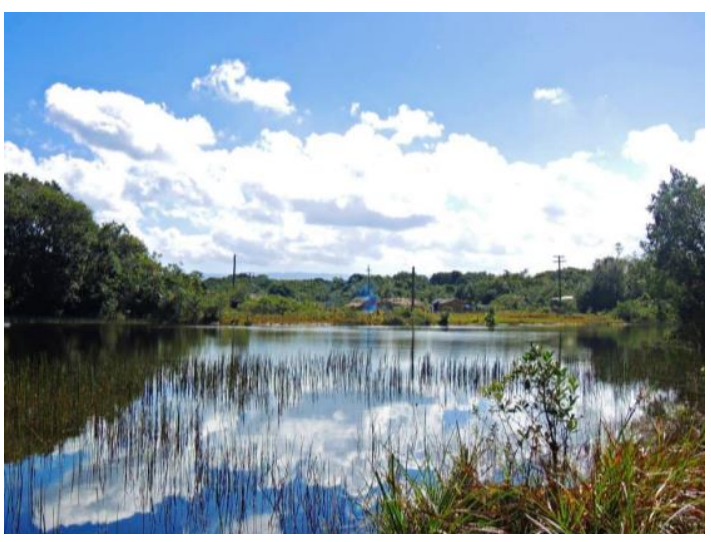

Figura 2: Espaço Contemporâneo da aldeia Tabaçú Reko Ypy. Itanhaém-Peruíbe/SP.

Figure 2: Contemporary space of village Tabaçú Reko Ypy. Itanhaém-Peruíbe/SP.

Fonte: VIVAOKATUR, 2015.

\section{A proposta do Turismo Étnico da aldeia Tabaçú Reko Ypy}

Itá Mirim deu início as suas atividades socioeducativas, de resgate e resistência a cultura indígena, em 2004, quando ainda fazia parte da aldeia Piaçaguera. Devido aos conflitos internos, os seus projetos não chegaram a gerar frutos. Ela explica um pouco sobre este fato: 
Desde 2004 iniciamos um trabalho de fortalecimento tradicional do nosso povo. São muitos os obstáculos para conseguirmos alcançar nossos objetivos, mas com a união de alguns líderes jovens e anciões estamos em busca desse fortalecimento. Dentro desse propósito nasceu a junção de fortalecimento e geração de renda para a auto sustentabilidade das famílias indígenas que, sempre de modo precário e sem valorização, comercializam seus artesanatos, palmito, plantas ornamentais e medicinais em feiras e praças (VIVA OKATUR, 2015).

Fundar a aldeia Tabaçu Reko Ypy permitiu que os indígenas colocassem em prática os seus projetos de valorização a vida e de resgate cultural, além de favorecer a busca de recursos financeiros através da educação socioambiental junto ao turismo étnico.

Os visitantes têm a oportunidade de vivenciar um modelo alternativo, conhecer um pouco sobre a sua história, suas lendas, músicas, arte, idioma e filosofia. Para os indígenas, trata-se de uma relação na qual seus ensinamentos são transmitidos com o intuito de serem respeitados e, de certa forma, conhecer um pouco mais sobre outras culturas. O povo da aldeia Tabaçú Reko Ypy diz se sentir mais estimulado a cuidar da aldeia, e de tudo que a complementa quando estão em fase de organização para receberem os visitantes para as atividades e vivências. Tal fato move os integrantes da aldeia a cuidarem do seu espaço, a buscarem matéria-prima para a produção de seus artesanatos e tintas naturais.

Para tanto, as atividades desenvolvidas e aplicadas na aldeia Tabaçu Reko Ypy têm como meta, visão e objetivo:
Arquitetura, manuseio de matérias primas, plantio, horta, criação de peixe, oficina de artesanato, visitação turística, museu histórico, esporte, lazer;
Encontros indígenas para incentivar as práticas tradicionais, a fim de fortalecer a raiz tradicional, combatendo a exposição à dependência química, à marginalidade e o alcoolismo;
Possibilitar principalmente aos jovens o aumento de sua autoestima e o orgulho de se autodenominar indígena;
Resgatar a língua indígena para os que não falam fluentemente, e com isso combater a discriminação sofrida por parte de grupos indígenas de língua próxima que caçoam e não os reconhece como irmãos (VIVA OKATUR, 2015).

Doria (2004), sugere que o ecoturismo pode concretizar benefícios a gestão ambiental local e ao mesmo tempo estimular a criação de novas áreas de conservação. Segundo a autora, este benefício ocorre em São Jorge do Alto Paraíso, no estado de Goiás, com a implantação de outras novas Reservas de Patrimônio Particular Natural. 
Os indígenas da aldeia Tabaçú Reko Ypy possuem ciência, discernimento e liberdade de escolha e opinião sobre o turismo étnico. Eles discutem por meio de reuniões entre todos da comunidade e avaliam juntos sobre os diversos aspectos relacionados aos impactos e as possíveis interferências e, para tanto, buscam sempre tomar cuidado para que este tipo de atividade não os prejudique.

\section{A organização do Turismo Étnico na prática com o povo Ñandeva.}

No ano de 2013 ocorreu a participação no evento chamado Vivência da Aldeia, cuja finalidade era a de mostrar ao visitante um pouco sobre o seu cotidiano e costumes e, através disso, obter renda financeira para investir em estruturas necessárias ao melhoramento das condições vigentes. Este evento foi promovido em parceria com a Agência de Monitores Ambientais, a AMA Ecoturismo, instituição que organizava e divulgava os eventos desta comunidade.

Conforme informado pela liderança da aldeia Tabaçú Reko Ypy, esta iniciativa se deu através dos idealizadores indígenas Itá Mirim, Morubixaba e Nhantze em parceria com a AMA Ecoturismo, quando ainda faziam parte da aldeia Nhamandú-Mirim. Devido a divergência de ideologias no que se refere ao projeto de resistência e resgate as tradições indígenas, ocorreu então, em 2012 uma separação interna, ou seja, os indígenas que eram a favor de colocar em prática as ideias relacionadas ao Turismo Étnico em prol da etnoconservação saíram da aldeia Nhamandú-Mirim e fundaram a aldeia Tabaçú Reko Ypy.

As vivências eram divulgadas através de uma página em rede social pela AMA Ecoturismo. A participação consistia em enviar e-mail à agência, efetuar a inscrição e contribuir com uma taxa de inscrição. Existia um limite de inscritos de no máximo 30 pessoas por vivência. Após a efetivação da inscrição, o participante recebia via e-mail os seguintes anexos: mapa de localização da região, instruções de como chegar até o local e sobre o que levar, mini-dicionário Tupi-Guarani, breve histórico da aldeia Tabaçú Reko Ypy, termo de compromisso e, por fim, um questionário de percepção ambiental que deveria ser enviado via correio eletrônico antes do evento.

De modo geral, a Vivência na Aldeia se baseia em expor aos visitantes - através de diálogo, rituais de pintura, cantos e encenações um 'resumo' sobre os seus costumes e tradições. O grupo também conta sobre a sua história, o porque estão lá sob aquelas condições, quais são os seus desafios e objetivos com relação a proposta de turismo, a importância sobre a resistência e o resgate cultural. Também, em alguns momentos ocorrem algumas atividades interativas - dinâmicas de sensibilização ambiental aplicadas pelos representantes da AMA Ecoturismo. No final do dia, os visitantes podem se banhar no lago e a noite, participam do tataruçú. 


\section{O turismo indígena realizado na aldeia}

A seguir o Quadro 1 apresenta resumidamente como são as atividades e encontros realizados na aldeia Tabaçú Reko Ypy:

Quadro 1: Programação das atividades desenvolvidas nos eventos da aldeia Tabaçú Reko Ypy, em Itanhaém-Peruíbe no período de 2013 a 2015.

Table 1: Programming of activities developed in the events of the village Tabaçú Reko Ypy in Itanhaém-Peruíbe in 2013 to 2015 period.

\begin{tabular}{|c|c|c|}
\hline DATA & ENCONTRO & PROGRAMAÇÃO \\
\hline 23/02/2013 & \multirow{2}{*}{ Vivência na aldeia I } & $\begin{array}{l}\text { Recepção. Café da manhã. Dinâmica. Ritual } \\
\text { de Pintura. Curso teórico-prático: Permacultura } \\
\text { | Bioconstrução. Almoço. Sensibilização } \\
\text { Ambiental (trilha sensitiva). Lazer. Tatáruçú. }\end{array}$ \\
\hline $24 / 02 / 2013$ & & 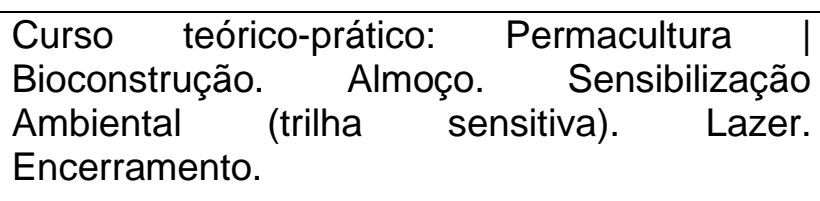 \\
\hline $09 / 11 / 2013$ & Vivência na aldeia II & $\begin{array}{l}\text { Recepção. Café da manhã. Dinâmica. Almoço. } \\
\text { Sensibilização Ambiental (trilha } \\
\text { Museu Vensitiva). }\end{array}$ \\
\hline 26/07/2014 & Vivência na aldeia III & $\begin{array}{l}\text { Recepção. Café da manhã. Dinâmica. Almoço. } \\
\text { Sensibilização Ambiental (trilha } \\
\text { Museu Vensitiva). Lazer. Encerramento. }\end{array}$ \\
\hline $16 / 10 / 2015$ & \multirow{3}{*}{ I Viva Okatur } & Recepção. Jantar. Tataruçú. Ritual de Pintura. \\
\hline 17/10/2015 & & $\begin{array}{l}\text { Desjejum. Curso I: Nativos Brasileiros. } \\
\text { Almoço. Curso II (Parte I): Conhecimentos } \\
\text { básicos de Sobrevivência na Mata. Jantar. } \\
\text { História ao pé do fogo e mbokwerá tata } \\
\text { (fogueira da cura) }\end{array}$ \\
\hline 18/10/2015 & & $\begin{array}{l}\text { Desjejum. Curso II - Continuação. Almoço. } \\
\text { Trilha interpretativa e apresentações } \\
\text { tradicionais Tupi-Guarani. Eura Tupãa } \\
\text { Nhanderú [Nomenclatura dos formados } \\
\text { guerreiros e encerramento]. }\end{array}$ \\
\hline
\end{tabular}

Fonte: Cássia Praeiro (2013).

A primeira vivência aconteceu nos dias 23 e 24 de fevereiro de 2013. Este primeiro encontro foi organizado pelos indígenas da aldeia Tabaçu Reko Ypy em parceria com a AMA Ecoturismo, responsável pela divulgação do evento nas redes sociais e pelas atividades socioeducativas; e os seguintes coletivos: a Anarco Filmes Produções, a qual colaborou com o curta-metragem divulgando a aldeia e também o seu trabalho. Os coletivos Cultive Resistência Semente Negra, este ministrou um curso teórico-prático sobre permacultura e a equipe do Hângü Cozinha Livre que preparou todo o alimento vegetariano e vegano para o público. $\mathrm{O}$ registro deste encontro está retratado em um vídeo produzido voluntariamente pela Anarco Filmes Produções. $O$ curta retrata um pouco sobre as atividades e sentimentos vividos durante o projeto "Vivência na Aldeia I: Permacultura ${ }^{18}$, Educação Ambiental e Tradições Indígenas". 
Esta vivência contou com a participação de cerca de oitenta pessoas - entre todos os envolvidos (indígenas, visitantes e coletivos).

A organização das ideias e propostas surgiu através de reuniões entre indígenas e parceiros. Para tanto, todos os envolvidos contribuíram de maneira mútua para a realização desta vivência e divulgação de seus trabalhos.

Com relação à distribuição financeira entre todos os envolvidos, os líderes da aldeia Tabaçu Reko Ypy informaram que todo o dinheiro arrecadado das inscrições foi investido em materiais e custos, como: argila, areia, alimentos, gás de cozinha, entre outras despesas.

A proposta deste projeto foi a de partilhar com os visitantes a história e o estilo de vida dos indígenas, unindo algumas atividades e dinâmicas de interpretação e sensibilização ambiental. Também foi possível aprender sobre algumas técnicas de permacultura - bioconstrução (superadobe e pau-a-pique) - para a construção de duas casas no espaço contemporâneo da aldeia, no qual os visitantes aprenderiam determinadas técnicas na prática e os indígenas, por sua vez, usufruiriam das casas, uma vez que, ainda não havia praticamente nada naquele espaço, apenas algumas paredes em lonas.

Ború relata que, aprender sobre novas ferramentas, técnicas de cultivo e de manejo com a terra - permacultura - são práticas essenciais que podem contribuir de maneira eficaz para o trabalho do povo Ñandeva. Afinal, a condição do território ainda não é autossuficiente para suprir as necessidades de todas as famílias daquele local. O roçado ainda se encontra improdutivo devido ao solo empobrecido. Por esta razão, os Nandeva são obrigados a consumir alguns alimentos que não fazem parte da sua dieta natural - como o arroz, o feijão e grãos.

A coleta seletiva - separação dos resíduos orgânicos e inorgânicos; o tratamento de compostagem para produção de húmus, produto utilizado para adubar o roçado; a escolha e uso eficiente de técnicas ambientalmente saudáveis como a bioconstrução e o banheiro seco são medidas alternativas que foram aprendidas e estão sendo praticadas na aldeia, devido à ausência de saneamento básico no local.

Segundo Araújo e colaboradores (2013), a Educação Ambiental (EA) e o ecoturismo deveriam formar parcerias e caminharem juntos na busca de um desenvolvimento local com base sustentável. Dentro deste contexto, Silva, Rabelo e Rodriguez (2011) citam a permacultura como uma das possíveis ferramentas alternativas, capaz de oferecer desenvolvimento para uma gestão que possibilite a evolução de suas atividades econômicas sustentáveis, beneficiando assim todos os integrantes da comunidade.

Com relação ao ritual de pintura, Itá Mirim $^{19}$ explica que, a arte corporal não se limita, ou seja, existem diversos tipos de pintura adequadas aos momentos: realce a beleza, cotidianas, guerreiros, de caça, específicas para determinados rituais e celebrações. Segundo Oliveira (2006), a arte de fazer as pinturas corporais pode ser considerada uma atividade voltada para a valorização cultural. $\mathrm{Na}$ população indígena Krahô, a tonalidade avermelhada do urucum se destaca em sua pele principalmente quando 
realizam os rituais e as corridas da flecha e da tora. É possível observar que o povo Nandeva utiliza muito a cor preta em seus traços artísticos corporais e a cor vermelha em suas vestimentas, simbolizando o sangue, a vida. Como matéria-prima utilizam o jenipapo, o urucum e, em último caso, o carvão. Se pintar é como 'se vestir' para uma determinada celebração.

O segundo encontro, nomeado "Vivência na Aldeia: Educação Ambiental e Tradições Indígenas", foi realizado no dia 09 de novembro de 2013, das $10 \mathrm{~h}$ às $17 \mathrm{~h}$. Este foi o primeiro contato desta pesquisa com o povo Nandeva.

A proposta desta vivência foi a de aplicar atividades lúdicas sensoriais junto à comunidade indígena. $\mathrm{O}$ evento almejava promover a inclusão social e a geração de renda da comunidade indígena, em combate ao preconceito, a discriminação de raça, de etnia e de condição econômica, assim como também proposto na III Vivência na Aldeia, realizada no dia 26 de julho de 2014, das 9h às 17h (VIVENCIA NA ALDEIA, 2013).

A terceira Vivência na Aldeia demorou a acontecer por conta dos longos períodos chuvosos ocorridos na região e também por algumas dificuldades internas relacionadas a desentendimentos e divergências de ideias e ideais entre indígenas e parceiros, como também pela falta de matéria-prima para se produzir os artesanatos que são vendidos durante 0 encontro, conforme informado pelos líderes da aldeia Tabaçú Reko Ypy.

Sendo assim, mesmo diante de tantos desafios, em agosto de 2015 o povo Nandeva, de maneira independente, divulgou a sua primeira Vivência, agora chamada Viva Okatur - Nhanderekó, cuja finalidade foi a de receber grupos interessados para conhecer e vivenciar junto aos indígenas a sua cultura por meio de trilhas interpretativas, canto e dança, atividade esportiva tradicional, lendas encenadas, exposição de artesanatos para venda, cursos sobre povos nativos brasileiros, instruções básicas de sobrevivência na mata, segundo conhecimento indígena Tupi-Guarani, entre outras atividades. Esta vivência foi realizada nos dias 16, 17 e 18 de outubro de 2015.

Embora o valor de acesso à visitação da aldeia Tabaçú Reko Ypy tenha aumentado radicalmente neste último encontro, se faz necessário notar que os investimentos para poderem oferecer uma vivência de duas noites e três dias, incluindo materiais didáticos, alimentação integral, camping, manutenção, reformas e melhoria da infraestrutura local, além de gás e outros custos, o valor cobrado por pessoa, ainda não cobriu todos os gastos, conforme relatado 20 por Morubixaba e Itá Mirim em janeiro de 2016. Ainda assim, afirmaram estarem felizes pela realização da vivência oferecida, pois se sentem vivos em poderem disseminar seus conhecimentos.

É notório perceber o quanto o povo Nandeva da aldeia Tabaçú Reko Ypy deseja buscar oportunidades e melhorias em suas terras e em seu cotidiano através de seus projetos relacionados a um perfil de turismo que possa promover um modelo de educação, conservação e desenvolvimento a toda comunidade, ou seja, busca-se alcançar um etnodesenvolvimento de qualidade e coerente com suas propostas. 
Sobre os impactos ambientais todo e qualquer tipo de turismo, incluindo o ecoturismo, produzem um impacto ambiental negativo, que pode ser maior ou menor. Embora o ecoturismo assuma um perfil de turismo ambientalmente sustentável, as suas práticas podem ser danosas quando exercidas de maneira inadequada em ecossistemas muito frágeis (LUÍNDIA, 2007).

Diante das observações realizadas em encontros relacionados sobre o pré-desenvolvimento da programação e também durante os eventos, notou-se a dedicação e a criatividade da comunidade Ñandeva, em criar, desenvolver e aplicar uma programação interessante e fiel aos seus objetivos no que diz respeito ao combate ao preconceito e a valorização de sua cultura.

Nas vivências anteriores a $E A$ se resumia em dinâmicas de sensibilização e interpretação do meio. Não que isso não seja importante, agrega valor e conhecimento a todos os envolvidos, mas de acordo com Pedrini (2007), para que seja possível explorar mais esta proposta é de grande valia verificar se a EA realmente está sendo aplicada e desenvolvida durante as trilhas interpretativas ou não. Para isso se faz necessária uma avaliação por um analista ou guia capacitado em EA. Tais dinâmicas poderiam também envolver mais o povo Nandeva.

Com relação as atividades de vivência praticadas até o ano de 2014, onde havia o auxílio entre parceiros externos, inevitavelmente havia de certa forma a interferência nas decisões relacionadas ao desenvolvimento e a programação das vivências. Um exemplo era a grande vontade do povo Nandeva aplicar uma vivência cuja a principal proposta se referia a oferecer um curso prático de Tõndaros ${ }^{21}$, contendo mais momentos de diálogo e reflexões sobre a cultura indígena e também poder oferecer aos visitantes a sua culinária tradicional. Essa vontade foi realizada no I Viva Okatur Nhanderekó onde puderam organizar e aplicar a proposta de maneira autônoma.

O "curso básico de sobrevivência na mata e nativos brasileiros" ministrado por Itá Mirim, Ború (morubixaba) e Tõndaros resultou em um material didático informativo sobre a cultura indígena, esclarecendo conceitos como etnia, costumes, diversidade de idiomas, aldeias, música, danças, ritos de passagem, tecnologias e suas políticas. Este material serviu de apoio durante discussão ministrada na escola da aldeia por Itá Mirim no dia 17 de outubro de 2015. A atividade prática foi aplicada por Ború e quatro Tõndaros nos dias 17 e 18 de outubro de 2015. Os visitantes foram convidados a caminhar por trilhas onde durante o percurso os indígenas explicavam sobre a fauna e a flora local, curiosidades e histórias. Também foi ensinado sobre prática de sobrevivência na mata, técnicas de defesa contra animais predadores, sendo os mais comuns, a onça-pintada, o porco selvagem, serpentes e demais animais peçonhentos ${ }^{22}$. Por fim, como encerramento da atividade prática, os visitantes aprenderam como construir cabanas com folhas de palmeiras.

Nhantze liderava e abençoava os rituais na fogueira e as demais mulheres da aldeia preparavam as refeições, enquanto as crianças 
brincavam livres e se interagiam em todos os momentos com os visitantes e parentes.

Entre tantas novidades, a culinária preparada e oferecida pelo povo Nandeva enriqueceu a vivência e aproximou ainda mais todos os integrantes envolvidos. De acordo com Cardozo (2006), colocar a gastronomia em evidência em experiências turísticas, especialmente com as de cunho cultural, seria também preencher essa vivência com sabor e aroma que tornariam o produto turístico único, permeando as lembranças do visitante sobre tão peculiar ponto de cultura de localidades visitadas.

Embora com programação interessante, incluindo a oferta da alimentação e material didático aos visitantes, o evento, diferente dos anteriores, obteve apenas 15 inscrições efetivas. Provavelmente isso tenha acontecido devido a alteração de valores e o canal de divulgação não tenha favorecido o preenchimento de vagas. O povo Nãndeva não obteve lucros financeiros, porém, demonstraram em entrevista, grande satisfação em poder compartilhar o seu conhecimento.

Em janeiro de 2016 a comunidade indígena Tabaçú Reko Ypy recebeu o prêmio de participação e classificação do edital de Seleção Pública $\mathrm{n}^{\circ}$ 02, de 02 de julho de 2015 do Ministério da Cultura - MinC com o projeto: Ao redor do Tataruçú (DOU, 2015). O projeto escrito com a ajuda de amigos de confiança deles foi um dos classificados. Através desta remuneração, o povo Nandeva está se dedicando a melhoria da infraestrutura da aldeia para o recebimento de turistas e também a construção da tão sonhada Oguatsu $^{23}$. Após a finalização desta poderão oferecer um espaço de qualidade para dar andamento as suas atividades turísticas.

Itá Mirim ${ }^{24}$ conta que, quando se inicia uma nova aldeia, o primeiro passo consiste em construir o Oguatsu, E para que seja possível a realização desta obra a coleta das folhas deve ser feita em épocas e na Lua adequada, ou seja, desde a colheita até a construção da casa sagrada se pratica os rituais sagrados em todas as etapas, ao adentrar a mata, permanecer e sair dela até a sua construção final. Tal matéria-prima, a palha, só se encontra em aldeias afastadas e para isso, dependem de recurso financeiro para contar com o transporte - carreto - alimentação para todos e demais gastos.

De acordo com a nova reformulação das vivências, o povo Nandeva da aldeia Tabaçú Reko Ypy se aproxima do conceito de turismo de base comunitária. Este segmento é uma estratégia de sobrevivência, e de entrada daqueles de menores condições econômicas na chamada cadeia produtiva do turismo. Uma forma de turismo que pensa o lugar, a conservação ambiental e a ressignificação da cultura, a sobrevivência e não a acumulação, embora nem sempre os resultados sejam tão positivos (CORIOLANO, 2006).

Nota-se o princípio de uma transformação no que se refere às práticas de turismo que começarão a ser exercidas na aldeia Tabaçú Reko Ypy. Determinados conflitos, inevitavelmente colaboraram para que agora se iniciasse uma mudança de perfil; a junção de um turismo étnico seguindo diretrizes de um turismo de base comunitária poderá favorecer a conquista de um etnodesenvolvimento local responsável. 


\section{Resultados e Discussão}

Em outras visitas realizadas em abril e junho de 2015 foi possível observar e participar mais do cotidiano do povo Nandeva.

Tais fatos relacionados a alguns conflitos, decepções e mudanças fizeram com que os indígenas tomassem a decisão de desenvolver e aplicar os seus projetos de maneira autônoma.

Os líderes indígenas nitidamente percebem que o caminho para a auto sustentabilidade e para o resgate e fortalecimento das tradições da sua comunidade se dará através do turismo étnico, pois é a partir desta ferramenta que seu povo obterá renda financeira para estruturar toda a sua aldeia e ao mesmo tempo, partilhar sobre seus valores éticos com os visitantes que desejam conhecer a sua cultura. Porém, reconhecem que não possuem domínio total com relação a organizações técnicas de divulgação, administrativas e financeira. Para isso estão contando com o apoio de amigos para divulgação do evento, fotografias e dicas de gestão.

$\mathrm{O}$ turismo em territórios indígenas tem adquirido características peculiares de cada etnia, pois cada uma se encontra num estágio diferente de organização para o turismo. Vale ressaltar que, se faz notória a ausência de uma proposta concreta que viabilize sua organização (OLIVEIRA, 2006). Essa falta de assistência para projetos em aldeias indígenas também é relatada por Grünewald (2003), nas TI de Barra Velha e de Coroa Vermelha localizadas na Bahia. Segundo Grünewald, além da dimensão política local, se faz necessário também pensar modelos de etnodesenvolvimento para as populações indígenas considerando-se vários elementos: história, cultura, religião, economia, políticas públicas, relações inter étnicas, fluxos culturais globais, além dos aspectos propriamente científicos e tecnológicos. Silva e colaboradores (2011), ao abarcarem a temática da EA em TI por meio do turismo são enfáticos ao afirmarem que tais ações também necessitam de um planejamento estratégico bem definido que oriente as ações da comunidade visando o mínimo de impacto possível na natureza e na cultura da comunidade indígena.

Entende-se que o planejamento participativo do turismo junto às comunidades indígenas brasileiras pode ser instrumento de transformação e valorização de elementos culturais tradicionais na composição da atividade, além daqueles considerados "novos" ou "inventados" para a produção turística (JESUS, 2012).

Através desta pesquisa in loco e das entrevistas realizadas, é perceptível o quanto o povo Nandeva da aldeia Tabaçu Reko Ypy deseja buscar oportunidades e melhoria em suas terras e em seu cotidiano através de seus projetos relacionados a um perfil de turismo que possa promover um modelo de educação, conservação e desenvolvimento a toda comunidade, ou seja, busca-se alcançar um etnodesenvolvimento de qualidade e coerente com suas propostas. 


\section{Conclusão}

O turismo a ser praticado pelo povo Nandeva se encontra em fase experimental e de adequação. Pelo que foi observado e de acordo com as mudanças ao longo dos anos, percebe-se estar havendo uma junção entre dois segmentos do turismo: o étnico e o de base comunitária. Embora saibam sobre a aculturação e os novos modelos em prol de melhorias e qualidade de vida, o principal desafio se dá em resgatar e fortificar suas tradições e se tornarem autossustentáveis através da prática do Turismo Étnico como ferramenta de apoio para o alcance do etnodesenvolvimento endógeno.

Mesmo já tendo experimentado algumas vivências com os visitantes até o momento, tudo ainda se encontra em fase de testes. O Turismo Étnico é uma alternativa de geração de renda que pode ou não colaborar com o resgate de identidade cultural, bem como o reconhecimento e a administração de suas potencialidades locais. Para tanto, é preciso estar ciente sobre os possíveis riscos e vantagens.

O povo Ñandeva afirma ainda não ter obtido lucros financeiros com este trabalho, mas os indígenas da comunidade gostam de exercer essa prática, pois relatam que se sentem vivos e orgulhosos em poder mostrar a sua cultura e transmitir mensagens de respeito ao próximo e à natureza. Tais atividades os tornam conhecidos na região, trazendo a possibilidade de novos trabalhos e lutando assim, contra o preconceito que o seu povo enfrenta cotidianamente.

Para que seja possível ocorrer uma transformação consistente e sustentável, os indígenas necessitam de uma capacitação, estrutura e organização para poderem cumprir com mais segurança a sua gestão e etnodesenvolvimento. Parcerias e apoios também são importantes e necessários e os indígenas não descartam tais possibilidades futuras desde que o resgate de sua cultura, a programação de suas vivências e o ambiente onde vivem não sejam demasiadamente alterados e prejudicados. Tal fato somado às condições atuais do território ainda frágil e incapaz de produzir e de garantir o sustento da comunidade mostra uma realidade em que o etnodesenvolvimento começará a gerar frutos por um período a longo prazo e através de muita persistência, com amadurecimento a cada passo.

Promover atividades esporádicas e de pequena escala evitará desgastes desnecessários no ambiente e interferências em suas tarefas cotidianas. Este sistema de visitação controlada é uma estratégia de conservação ambiental favorável capaz de contribuir para um turismo organizado e autêntico, se tornando um diferencial entre as demais atividades de turismo praticada em outras aldeias da região.

Melhorar a infraestrutura e controlar o número de visitantes são ações que contribuem para a qualidade do serviço prestado e que podem reduzir possíveis impactos negativos no local. O marketing turístico deve ser honesto, estratégico e inteligente, evitando distorções culturais e a massificação desta atividade. Também se faz necessário pensar sobre a saúde e a segurança do local como forma de evitar possíveis acidentes, contatos e conflitos com drogas, abusos e violência. 
Obter conhecimento e fazer uso de ferramentas alternativas e limpas também pode favorecer o sucesso, a autonomia, o empoderamento nas decisões a serem tomadas e a restauração do ecossistema degradado. Este aprender irá de certa forma interferir na cultura da comunidade, porém, é preciso compreender que as sociedades passam por processos dinâmicos e contínuos que são capazes de favorecer determinadas transformações. É preciso saber ponderar, quando necessário, discernir sobre o que é bom e útil para buscar melhorias na qualidade de vida e na sustentabilidade financeira, ambiental e sociocultural.

As diretrizes do capital social e o apoio de colaboradores podem contribuir positivamente para o alcance do etnodesenvolvimento. É possível praticar um modelo de Turismo de Base Comunitária que faça uso de técnicas pedagógicas e que também utilize a Educação Ambiental como ferramenta de apoio à percepção e a sensibilização. Envolver e incluir todos os membros da comunidade poderá fortalecer os laços familiares e a autoestima entre todos os envolvidos. Para tanto, também se faz necessário se atentar sobre as possíveis consequências negativas que o turismo pode trazer, como a degradação ambiental de um ecossistema frágil em recuperação, o consumo excessivo dos recursos naturais locais e a perda de sua privacidade e identidade cultural.

Igualmente devem se policiar para não serem vistos e julgados pelo público como apenas mais uma aldeia personificada, pois na região são vistos e respeitados pela sua fidelidade e comprometimento com as suas raízes. Embora saibam sobre os desafios a serem encarados com determinação e organização, os indígenas se mantém otimistas diante de qualquer dificuldade enfrentada até o momento.

Aprender com ações que não deram certo, arriscar e analisar sobre as possíveis consequências são experiências importantes para que seja possível prosperar de maneira prudente e consistente ao sucesso do etnodesenvolvimento responsável e sustentável através do turismo étnico e o de base comunitária.

\section{Referências bibliográficas}

AMATUZI, B.; BOTEGA, J.L.; CELANTE, L.S. Implementação de banheiro seco como proposta de saneamento ecológico. Paraná. 63f. Monografia (Trabalho de Conclusão de Curso em Tecnologia em Gestão) - Universidade Tecnológica Federal do Paraná, 2013.

ARAÚJO, F.X.S; SANTOS, E.S.; ESTEVES, L.U.; SILVA, T L. Educação Ambiental nas sociedades indígenas brasileiras: uma breve análise. Holos, Amapá: Universidade Federal do Amapá, v. 05, p. 282-292, 2013.

AZANHA, G. Etnodesenvolvimento, mercado e mecanismos de fomento: possibilidades de desenvolvimento sustentado para as sociedades indígenas no Brasil. In: LIMA, A.C.; BARROSO-HOFFMANN, M. (Orgs.). Etnodesenvolvimento e políticas públicas: bases para uma nova política indigenista. Rio de Janeiro: Contra-Capa/LACED, p. 29-38, 2002. 
AZEVEDO, P.M.P.; FERREIRA, A.; ANDRADE, M.O. Etnodesenvolvimento local, contraponto ao capitalismo: pressupostos teóricos e sua interface para análise de uma comunidade. Revista Brasileira de Antropologia, Natal, n. 29, p.13, ago. 2014.

BAINES, S. 2014. Terras indígenas apresentam os menores índices de devastação. Disponível em: <http://www.valor.com.br/agro/3702128/terrasindigenas-apresentam-os-menores-indices-de-devastacao > . Acessado em: 01 mai. 2014.

BARTHOLO, R.; SANSOLO, D.G.; BURSZTYN, I. Turismo de base comunitária: diversidade de olhares e experiências brasileiras. (Orgs.). - Rio de Janeiro: Letra e Imagem, 2009.

BATALLA, G. B et al. America Latina: etnodesarollo, etnocidio. Costa Rica: FLACSO, 1982.

BANDUCCI JR.; BARRETTO, M. Turismo e Identidade local: uma visão antropológica. Papirus: Campinas, SP: 2 ed., 2001.

BRASIL. Ministério do Meio Ambiente. Secretaria Nacional de Políticas de Turismo. Manual de Ecoturismo Indígena. Brasília: MMA, 1997.

BRASIL. Ministério do Turismo. Secretaria Nacional de Políticas de Turismo. Ecoturismo: Orientações Básicas. Brasília, 1998 e 2010.

BRASIL. Ministério do Turismo. Secretaria Nacional de Políticas de Turismo. Marcos Conceituais do Turismo. Brasília, 2005.

BRASIL. Ministério do Turismo. Secretaria Nacional de Políticas de Turismo. Roteiros do Brasil: Turismo e Sustentabilidade. Brasília, 2007.

BRASIL. Ministério do Turismo. Secretaria Nacional de Políticas de Turismo. Turismo cultural: orientações básicas. 2. ed. Brasília, 2008.

BRASIL. Ministério do Turismo. Turismo de Base Comunitária, 2008. Disponível em: <http://www.turismo.gov.br>. Acesso em: 11 jan 2015.

BRASIL. Ministério do Turismo. Edital MTur n.001/2008. Seleção de Propostas de Projetos para Apoio às Iniciativas de Turismo de Base Comunitária. Brasília, 2008.

CAMPBELL, D.; STANLEY, J. Experimental and quase-experimental designs for research. Boston: Houghton Miffllin, 1963.

CARDOZO, P. F. Considerações preliminares sobre produto turístico étnico. Pasos. Revista de Turismo y Patrimonio Cultural. Amapá: Instituto de Ensino Superior do Amapá. v.4, n.2, p.143-152, 2006.

CASTRO, V. M. Intersetorialidade e Transdisciplinaridade: Educação, Cultura Popular e Turismo Comunitário: O Caso da Ação Griô Nacional. Dissertação de Mestrado. João Pessoa. UFPB, 2009.

CENTRO DE INFORMAÇÃO TOXICOLÓGICA DO RIO GRANDE DO SUL. Animais peçonhentos. 2016. Disponível em: $<$ http://www.cit.rs.gov.br/index.php?option=com content\&view=category\&layout $=$ blog\&id=4\&ltemid=56 > . Acessado em 20 mar. 2016.

CESAR, P. Superadobe: construindo com o terreno. Rio de Janeiro, 2015. COMISSÃO PRÓ-ÍNDIO DE SÃO PAULO. Terras Indígenas na Mata Atlântica: pressões e ameaças. São Paulo: CPISP, 2010 e 2013. 
CORIOLANO, L.N.M.T. O turismo nos discursos, nas políticas e no combate à pobreza. São Paulo: Annablume, p. 198-213, 2006.

DORIA, C.R.C. Viabilidade do ecoturismo como alternativa de renda para comunidade na Amazônia. 310f. Tese (Doutorado). Núcleo de Altos Estudos Amazônicos, UFPA, 2004.

DIARIO OFICIAL DA UNIÃO. 2015. p. 18. Seção 1. Disponível em: $<$ http://www.cultura.gov.br/documents/10883/1312409/Portaria+n\%C2\%BA\%20 $\underline{61+d e+16.12 .2015}$ >. Acessado em: 21 mar. 2016.

FABEIRO, C.P. El desarrollo endógeno local, estúdio de la actividad turística como forma de aprovechamiento de los recursos: aplicación al caso del Baixo Miño. 2004. Vigo, 373f. Tesis (Doctorado em Ciencias Economicas) Departameno de Economía Aplicada, Universidad de Vigo, 2004.

FACO, R.A.; NEIMAN, Z. A natureza do ecoturismo: conceitos e segmentação. In: NEIMAN, Z.; RABINOVICI, A. (Orgs.). Turismo e Meio Ambiente no Brasil. Barueri, SP: Manole, 2010.

FARIA, I.F. Ecoturismo Indígena e valorização do patrimônio na região do Alto Rio Negro, 2007. Disponível em: $<$ http://www.ecoturismowanamei.com/espanol/tours indigena 7dias.php. $>$ Acessado em: 22 de jan. 2015

FUNDAÇÃO NACIONAL DO ÍNDIO - FUNAI. Modalidades de Terras Indígenas. 2015. Disponível em: <http://www.funai.gov.br/index.php/indios-nobrasil/terras-indigenas\#>. Acessado em: 25 mar. 2015.

GODOY, A. A pesquisa qualitativa e sua utilização em administração de empresas. Revista de Administração de Empresas, v. 35, n.4, p.65-71, 1995.

GOMES, M.P. Os índios e o Brasil: passado, presente e futuro. São Paulo: Contexto, 2012.

GRÜNEWALD, R.A. Etnodesenvolvimento indígena no Nordeste (e Leste): aspectos gerais e específicos. Revista Anthropológicas, ano 7, volume 14 (1 e 2):47-71, $2003 . \quad$ Disponível em: $<$ http://www.revista.ufpe.br/revistaanthropologicas/index.php/revista/article/view File/19/21>. Acesso em: 07 set. 2015.

HANAI, F.Y. Desenvolvimento sustentável e sustentabilidade do turismo: conceitos, reflexões e perspectivas. Revista Brasileira de Gestão e Desenvolvimento Regional. São Paulo: G\&DR, v.8, n.1, p. 198-231, jan./abr. 2012.

HOBSBAWM, E.; RANGER, T. (Orgs.). A invenção das tradições. Rio de Janeiro: Paz e Terra, 1984. p.. 9-23.

HOLMGREN, D. Os fundamentos da permacultura. Austrália, p. 3-27, 2007.

INSTITUTO SOCIOAMBIENTAL - ISA. Povos indígenas do Brasil: Guarani Ñandeva. 2008. Disponível em: <http://pib.socioambiental.org/pt/povo/guaraninandeva>. Acessado em: 20 nov. 2014.

LINDBERG, K.; HAWKINGS, E. Ecoturismo: um guia para o planejamento e gestão. 2. ed. São Paulo: [s.n.], 1999. 289p.

JESUS, D.L. A (re)tradicionalização dos territórios indígenas pelo turismo: um estudo comparativo entre os Kadiwéu (Mato Grosso do Sul - BR) e Maori (Ilha Norte - NZ). Tese (Doutorado). Curitiba: UFP, 2012. 
JONES, S.. The analysis of depth interviews. In: WALKER, R. (Ed.), Applied qualitative research (pp. 56-70). Aldershot (Hants.): Gower, 1985.

JULIANO, T; RABINOVICI, A. Turismo em território indígena. In: NEIMAN, Z.; RABINOVICl, A. (Orgs.). Turismo e Meio Ambiente no Brasil. Barueri, SP: Manole, 2010.

LUÍNDIA, L.A. Ecoturismo Indígena. 1ํ. Ed. - Quito: Abya-Yala, 2007.

MENESES, U. T. B. de. Os "Usos Culturais" da Cultura: contribuição para uma abordagem crítica das práticas e políticas culturais. In: YAZIGI, G.; CARLOS, A.F.A.; CRUZ, R.C.A. (Orgs.). Turismo: espaço, paisagem, cultura. São Paulo: Hucitec, 1996, p.88.

MOREIRA, M. A. Pesquisa em ensino: Métodos Qualitativos e Quantitativos. Porto Alegre: UFRGS, Brasil, 2009.

OLIVEIRA J. P.; FREIRE C.A.R. A Presença Indígena na Formação do Brasil. Brasília: Ministério da Educação, Secretaria de Educação Continuada, Alfabetização e Diversidade; LACED/Museu Nacional, 2006.

OLIVEIRA, E.S. Impactos socioambientais e econômicos do turismo e as suas repercussões no desenvolvimento local: o caso do Município de Itacaré - Bahia INTERAÇÕES. Revista Internacional de Desenvolvimento Local. Vol. 8, N. 2, Set. 2007.

ORGANIZAÇÃO MUNDIAL DO TURISMO. Guia de Desenvolvimento do Turismo Sustentável. Porto Alegre: Bookman, 2003.

PEDRINI, A.G. A educação ambiental no ecoturismo brasileiro - passado e futuro. In: SEABRA, G. (Org.). Turismo de Base Local: identidade cultural e desenvolvimento regional. João Pessoa: Editora Universitária / UFPB, 2007.

RODRIGUES, A.D. Línguas brasileiras: para o conhecimento das línguas indígenas. São Paulo: Edições Loyola, 2002.

SILVA, E.V.; RABELO, F.B.; RODRIGUEZ, J.M.M. (Org.). Educação Ambiental e Indígena: caminhos da extensão universitária na gestão de comunidades tradicionais. Fortaleza: Edições UFC, 2011.

SILVA, R.E; CARVALHO, C.D. O turismo de base comunitária como alternativa para o etnodesenvolvimento da comunidade quilombola de Filipa - MA. In: Anais do II Seminário Internacional de Turismo Sustentável. Fortaleza, 2008.

SILVA, M.O.L.; OLIVEIRA, S.S.; PEREIRA, V.A.; LIMA, M.G.S.B. Etnografia e Pesquisa Qualitativa: apontamentos sobre um caminho metodológico de investigação. Piauí: UFPI, 2011.

STAVENHAGEN, R. Las organizaciones indígenas: actores emergentes em América Latina. Revista de la CEPAL, n.62, p.61-73, 1997.

TARLOMBANI, M. A. Turismo, Políticas de Ordenamento Territorial e Desenvolvimento Regional. Curitiba, Tese (Doutorado) - Universidade de São Paulo, 2002.

VIVA OKATUR, 2015. Aldeia Tabaçu Reko Ypy. Disponível em: $<$ http://vivaokatur.blogspot.com.br/p/objetivo.html>. Acessado em: 02 out. 2015.

VIVÊNCIA NA ALDEIA. 2013. Documentário. Disponível em: $<$ http://www.youtube.com/watch?v=6saegdKv1uk>. Acessado em: 08 de set. 2013 
VIVÊNCIA NA ALDEIA. 2013. Documentário. Disponível em: $<$ http://vivencianaaldeia.org/>. Acessado em 05 jan. 2014.

VON HELD, A.A. Turismo em Terras Indígenas: Atravessando o portal com respeito. Brasília: CET, 2013.

YIN, R.K. Estudo de caso: planejamento e métodos. 3. ed. Porto Alegre: Bookman, 2005.

\section{Notas:}

${ }^{1}$ Refere-se aos grupos quilombolas, caiçaras, indígenas, caboclos, entre outros.

${ }^{2}$ Mirian Dina dos Santos Oliveira, na língua indígena, Itá Mirim (Pedra pequena), é formada em Pedagogia (Magistério Indígena) pela Universidade de São Paulo USP. É professora indígena a dez anos, leciona os idiomas tupy-guarani e língua portuguesa. É líder e coordena eventos culturais e projetos de fortalecimento tradicional da aldeia. Vice-Diretora da Escola Estadual Indígena Aldeia Nhamandú Mirim. Entrevista concedida à Cássia Praeiro em 27 de abr. de 2014.

${ }^{3}$ Há, contudo, entre os subgrupos Guarani-Ñandeva, Guarani-Kaiowa e GuaraniMbya existentes no Brasil, diferenças nas formas linguísticas, costumes, práticas rituais, organização política e social, orientação religiosa, assim como formas específicas de interpretar a realidade vivida e de interagir segundo as situações em sua história e em sua atualidade (ISA, 2008).

${ }^{4}$ Tabaçú Reko Ypy: Renascer da grande aldeia.

${ }^{5}$ Viva Okatur - Nhanderekó: Nosso modo de viver.

${ }^{6}$ Morubixaba também conhecido como Ború é o líder da aldeia. Os Ñandeva não gostam do termo Cacique, pois alegam que se trata de um termo ofensivo.

${ }^{7}$ Nhantze é a anciã da aldeia, a grande sábia, respeitada e responsável por muitos rituais praticados, principalmente os rituais de cura.

8 Jundú: termo indígena cujo significado se refere a 'mata ruim'.

${ }^{9}$ Entrevista concedida à Cássia Praeiro em 27 de abr. de 2014.

${ }^{10}$ Entrevista concedida à Cássia Praeiro em 27 de abr. de 2014.

${ }^{11}$ Superadobe: técnica de bioconstrução criada por Nader Khalili, arquiteto iraniano. A técnica consiste em facilitar a construção necessitando de menos tempo e custos, garantindo segurança e resistência. Os materiais necessários para se construir utilizando a técnica de superadobe são: areia, barro (argila), arame farpado, sacos polietilenos em rolo ou unidade - pode-se também reaproveitar sacos de ração para a construção da base das casas (CESAR, 2015).

${ }^{12} \mathrm{O}$ banheiro seco é uma alternativa de saneamento ecológico que não utiliza água em seu sistema para tratar os dejetos humanos que são armazenados em uma câmara onde passam por processo de compostagem. Este tipo de banheiro reduz consideravelmente ou totalmente o uso excessivo de água. Portanto, como não há mistura de água com os dejetos, não existe geração de esgoto doméstico, evitando possíveis doenças relacionadas a ela, assim como a possível contaminação de mananciais hídricos (AMATUZI; BOTEGA; CELANTE, 2013).

${ }^{13}$ Capiá: Planta da família das Poaceae e de porte herbáceo. Também conhecida como capim-de-nossa-senhora, capim-de-contas, capim-miçanga, capim-rosário, conta-de-lágrimas, contas-de-nossa-senhora, contas, lágrimas-de-jó, lágrimas-decristo, lágrimas-de-São-Pedro. 
14 Tatáruçú: Fogueira sagrada.

${ }^{15}$ Entrevista concedida à Cássia Praeiro em 27 de abr. de 2014.

${ }^{16}$ Nhanderekó: Cantos sagrados em agradecimento à Nanderu e aos elementos da natureza.

17 Nhanderú: Deus, o pai de todas as coisas.

${ }^{18}$ A palavra permacultura foi cunhada por Bill Mollison \& Holmgren em meados dos anos 1970 e definida da seguinte maneira: permacultura são paisagens conscientemente desenhadas que reproduzem padrões e relações encontradas na natureza e que, ao mesmo tempo, produzem alimentos, fibras e energia suficientes para prover as necessidades locais. As pessoas, suas edificações e a forma como se organizam são questões centrais para a permacultura. Assim, a visão da permacultura de uma agricultura permanente ou sustentável evoluiu para uma visão de uma cultura permanente sustentável. Inserida neste contexto a permacultura é fundamentada nos seguintes princípios éticos: cuidado com a terra (solos, florestas e água); cuidado com as pessoas (cuidar de si mesmo, parentes e comunidade) e; partilha justa (estabelecer limites para o consumo e reprodução, e redistribuir o excedente) (HOLMGREN, 2007).

${ }^{19}$ Entrevista concedida à Cássia Praeiro em 27 de abr. de 2014.

${ }^{20}$ Entrevista concedida à Cássia Praeiro em 06 de jan. de 2016.

${ }^{21}$ Tõndaros: Guerreiros, em tupi-guarani.

${ }^{22}$ Peçonhento é aquele que possui veneno e estrutura para inocular este veneno como por exemplo, serpentes (presas), aranhas (quelíceras), escorpiões (aguilhão) e lagartas (cerdas) (CIT, 2016).

23 Oguatsu: Casa grande aberta nas laterais, casa mística, sagrada, onde são realizados os rituais.

${ }^{24}$ Entrevista concedida à Cássia Praeiro em 11 de abr. de 2015.

Cássia Aparecida Praeiro Mateus: Universidade Federal de São Carlos, Sorocaba, SP, Brasil.

E-Mail: c.praeiro@yahoo.com.br

Link para o currículo Lattes: http://lattes.cnpq.br/3811691903946107

Andrea Rabinovici: Universidade Federal de São Paulo, Diadema, SP. Brasil.

E-Mail: andrearabinovici@gmail.com

Link para o currículo Lattes: http://lattes.cnpq.br/4506171831521594

Data de submissão: 11 de maio de 2016

Data de recebimento de correções: 16 de agosto de 2016

Data do aceite: 16 de agosto de 2016

Avaliado anonimamente 